\title{
Decision analysis of retirement age based on individual income equitable
}

\author{
Liu Zijun \\ (College of Economics and Management, Shenyang Aerospace \\ University, Liaoning Shenyang 110136, china)
}

\begin{abstract}
retirement age is the sensitive problem, it impact the profits which include country、 company labor and so on. Therefore, retirement age decision need broaden the scope. Personal income equity is an important variable. It is related to the enthusiasm of workers to take part in social endowment insurance. The paper collect data about salary distribution and social pension insurance since the pension system finished in China and use the time value of money. It analysis some various types of workers pension insurance income situation. Then this paper calculates the reasonable retirement age of all kinds of workers from the way of the fairness of the pension insurance income. Finally, it puts forward the proposal of designing the legal retirement age from the part of fair distribution of social income.

Key words : social pension insurance; individual income equitable;legal retirement age

Economic development, the extension of human life, the accelerated aging of the population, the social security system put forward new requirements, Retirement system is an important part of the national social security system. How to determine a scientific and reasonable retirement age for the balance of social security in relation to all subjects has important practical significance.

From the perspective of social income distribution fairness: The aim of the employee's pension insurance is to accumulate a pension for him. Therefore, the basic requirement to pay insurance is to keep the balance of personal pension payments. The basic model : the present value of the total amount paid by the
\end{abstract}


individual pensions $=$ the present value of the total amount paid by the individual pensions. In this model, the present value of the total amount paid by the individual pensions $=\sum x_{j} P_{(r / n)} k$, where $x_{j}$ is the individual workers in the first $\mathrm{j}$ years of wages $P_{(r / n)}$ is the interest rate for the first $\mathrm{n}$ years of compound interest present value of the coefficient $\mathrm{k}$ is the proportion of pension payments; the present value of the total amount paid by the individual pensions $=\sum Y_{j}^{\prime} P_{(i / n)}^{\prime}$, where $Y_{j}$ is the individual workers in the final $\mathrm{j}$ years of wages $P^{\prime}{ }_{(r / n)}$ is compound interest present value of the coefficient.

\section{The theories of social security income}

The model framework of social security for the pension insurance is the net present value of the social security wealth for the pension minus the amount of the pension insurance contribution. Therefore, retirement age as an independent variable, the social pension insurance benefit function is:

SSW is the social security wealth pension insurance income; $\mathrm{S}$ is the working age; Ris the retirement age; $\mathrm{YRET}_{\mathrm{t}}$ is the R-year-old workers in the $\mathrm{t}$ year-old pension income; $\mathrm{YLAB}_{t}$ is the net income of labor at the age of $t ; \mathrm{c}_{t}$ is the rate of the worker payment in $\mathrm{t}$-year -old; $\mathrm{a}_{\mathrm{t}}$ is the probability of survival for $\mathrm{S}$ aged persons to at least $\mathrm{t}$ years; Pis compound interest present value of the coefficient.

When the social pension insurance wealth effect is more than zero, said the employee pension income is greater than their work to pay pension insurance, that is to obtain the benefits of pension insurance; When the social pension insurance wealth effect is less than zero, said the employee pension income is less than their work to pay pension insurance, that is, the pension insurance loss. It is no doubt that, as a rational economic man's workers want to get old-age insurance benefits, But this thing to break the rational allocation of social resources. Try to guess that: If every employee get social security benefits of pension insurance benefits, that the operation of the social pension insurance fund is a loss . Therefore, from the perspective of social income distribution, pension income is zero situations are the social pension insurance income model balance. When the social pension benefit is zero, the model (1) becomes: the net present value of the pension income earned by an employee is equal to the sum of the net present value of the pension paid at work.

Residents to pay the insurance should be equal to retirement pension after retirement. In other words, social security benefits of old-age income are zero. Therefore, the legal retirement age is a function of the service, life expectancy, 
income level, pension extraction rate and pensionfrom Assign a fair point of income.

Calculating the pension insurance payments is so simple, generally by a certain percentage of income. Under normal circumstances, the pension insurance system in a country the proportion of pension payments is remain stable, and assume that everyone can live to the average life expectancy, .when this situation happened, the total amount of pension insurance should be paid : $=\sum x_{j} k P_{(r / n)}$

Calculating the pension insurance collection is so difficult。According the recently new about the way of calculating the pension insurance Retirement workers pension consists of two parts, the pension $=$ basic pension + personal account pension. Personal account pension is paid during the work of pension funds into the personal account of the part of this part of the funds exist in the personal endowment account, after retirement to install the pension to the way. Personal account pension is calculated as:

$$
Y_{1 i}=\frac{\sum x_{j} k}{R_{T}-R}
$$

In (2) model, $\mathrm{Y}_{1 \mathrm{i}}$ is the retired workers in the first $\mathrm{i}$ years of personal account pension; $\sum x_{j} k$ is the total of pension insurance payments at work $; \mathrm{R}_{\mathrm{T}}$ is life; $\mathrm{Ris}$ detainment age.

Part of the basic pension is the redistribution of the pension pool. The model is: basic pension $=$ (the region last on-the-job workers in the average income $+\mathrm{I}$ pay the average income index $) \div 2 \times$ years of payment $\times 1 \%$;Personal indexed average income $=$ average income in the region last month on-the-job workers $\times$ personal average contribution index, while the individual average contribution index is the actual payment base and the average income rate over the years. Thus, the basic pension model is calculated as follows:

$$
Y_{2 i}=X_{i-1}\left[1+\overline{\left(\frac{x_{j} \times k}{X_{j}}\right)}\right] \times \frac{1}{2} \times\left(R-R_{0}\right) \times 1 \%
$$

In (3) model,is the basic pension for retired employees for the first year;is the first $\mathrm{i}-1$ years of social average salary; is the average individual contribution Index of Workers; $\mathrm{R}_{0}$ is the first year to work。 According to the above analysis, we can sue (2) and (3) model to get the model of pension claim:

$$
\frac{\sum x_{j} k}{R_{T}-R}
$$

Therefore, the social pension benefits model is:

$$
\sum_{j=R_{0}}^{R} x_{j} k P_{(r / j)}
$$


Where the discount rate is the annuity present value coefficient of the pensionable year as RT-R; the other symbols are the same as above.

\section{The income of pension insurance of all types of workers under current retirement policy}

Task group collected the national average income of employees in 2000 from RMB9333.00 2013 to RMB51474.00; an average annual growth of $13.4 \%$. The average life expectancy at the end of the $1950 \mathrm{~s}$ was about 60 years. According to the 2010 census, the average life expectancy of men in our country was 72.38 for men and 77.37 for women. The average life expectancy was about 2 years per decade, and consideration was given to war, natural disasters, disease control and human body structure And other factors, the next 40 - 50 years, the average life expectancy of men 75 years old, 77-year-old woman.

Under the current education system, salary distribution system and retirement policy, there are differences in the educational level, gender, age, initial wage and retirement age. Therefore, accounting for social security benefits of old-age treatment should be classified. According to the current system of various types of workers to pay the pension insurance and receive basic information shown in Table 1.

Tabe1 comparison of different types of workers under current retirement system

\begin{tabular}{l|l|l|l|l}
\hline \multirow{2}{*}{ Education } & \multirow{2}{*}{$\begin{array}{l}\text { Starting } \\
\text { Working Age }\end{array}$} & $\begin{array}{l}\text { Starting Year } \\
\text { Salary }\end{array}$ & $\begin{array}{l}\text { Retirement age under the } \\
\text { current system }\end{array}$ \\
\cline { 3 - 5 } & & 27200 & 55 & Male \\
\hline $\begin{array}{l}\text { Junior high } \\
\text { school }\end{array}$ & 16 & 27400 & 55 & 50 \\
\hline High School & 19 & 27900 & 60 & 50 \\
\hline Specialist & 22 & 30480 & 60 & 55 \\
\hline Undergraduate & 25 & 51000 & 60 & 55 \\
\hline Postgraduate & 28 & Female \\
\hline
\end{tabular}

At present, The proportion of individual contributors in China's pension system is $20 \%, 8 \%$ of which enter individual accounts and the remaining $12 \%$ enter pooled funds, in other words, The amount of the employee's pension insurance payment is $20 \%$ of the personal wage income, it means $\mathrm{k}=20 \%$ 。 The one-year bank deposit rate as the discount rate, the total amount of all types of workers to pay the pension insurance can be seen in Table 2 . 
Tab 2 the measuring of pay the pension under current retirement system

\begin{tabular}{|c|c|c|c|}
\hline Education & sex & model & $\begin{array}{l}\text { The present } \\
\text { value of sum }\end{array}$ \\
\hline \multirow{2}{*}{$\begin{array}{l}\text { Junior high } \\
\text { school }\end{array}$} & Male & $\sum x_{j} k P_{(r / n)}=\sum_{j=16}^{55} 0.2 x \cdot P(2.75 \%, j)$ & 3546358.57 \\
\hline & Female & $\sum x_{j} k P_{(r / n)}=\sum_{j=16}^{50} 0.2 x \cdot P(2.75 \%, j)$ & 2000186.13 \\
\hline \multirow{2}{*}{ High School } & Male & $\sum x_{j} k P_{(r / n)}=\sum_{j=19}^{55} 0.2 x \cdot P(2.75 \%, j)$ & 2535271.94 \\
\hline & Female & $\sum x_{j} k P_{(r / n)}=\sum_{j=19}^{50} 0.2 x \cdot P(2.75 \%, j)$ & 1424329.50 \\
\hline \multirow{2}{*}{ Specialist } & Male & $\sum x_{j} k P_{(r / n)}=\sum_{j=22}^{60} 0.2 x \cdot P(2.75 \%, j)$ & 3245286.82 \\
\hline & Female & $\sum x_{j} k P_{(r / n)}=\sum_{j=22}^{55} 0.2 x \cdot P(2.75 \%, j)$ & 1828262.78 \\
\hline \multirow{2}{*}{ Undergraduate } & Male & $\sum x_{j} k P_{(r / n)}=\sum_{j=25}^{60} 0.2 x \cdot P(2.75 \%, j)$ & 2514538.98 \\
\hline & Female & $\sum x_{j} k P_{(r / n)}=\sum_{j=25}^{55} 0.2 x \cdot P(2.75 \%, j)$ & 1410358.80 \\
\hline \multirow{2}{*}{ Postgraduate } & Male & $\sum x_{j} k P_{(r / n)}=\sum_{j=28}^{60} 0.2 x \cdot P(2.75 \%, j)$ & 2977122.03 \\
\hline & Female & $\sum x_{j} k P_{(r / n)}=\sum_{j=28}^{55} 0.2 x \cdot P(2.75 \%, j)$ & 1659329.23 \\
\hline
\end{tabular}

According to the current social pension calculation method ofChina, the retirement pension by the individual account pension and basic pension in two parts.According to Table 1 and Table (2), calculate the individual employee's pension, and calculate the basic pension according to Table 1 and model (3), and then calculate the sum of all kinds of employees' retirement income in Table 3. 
Tab 3the measuring of get the pension under current retirement system

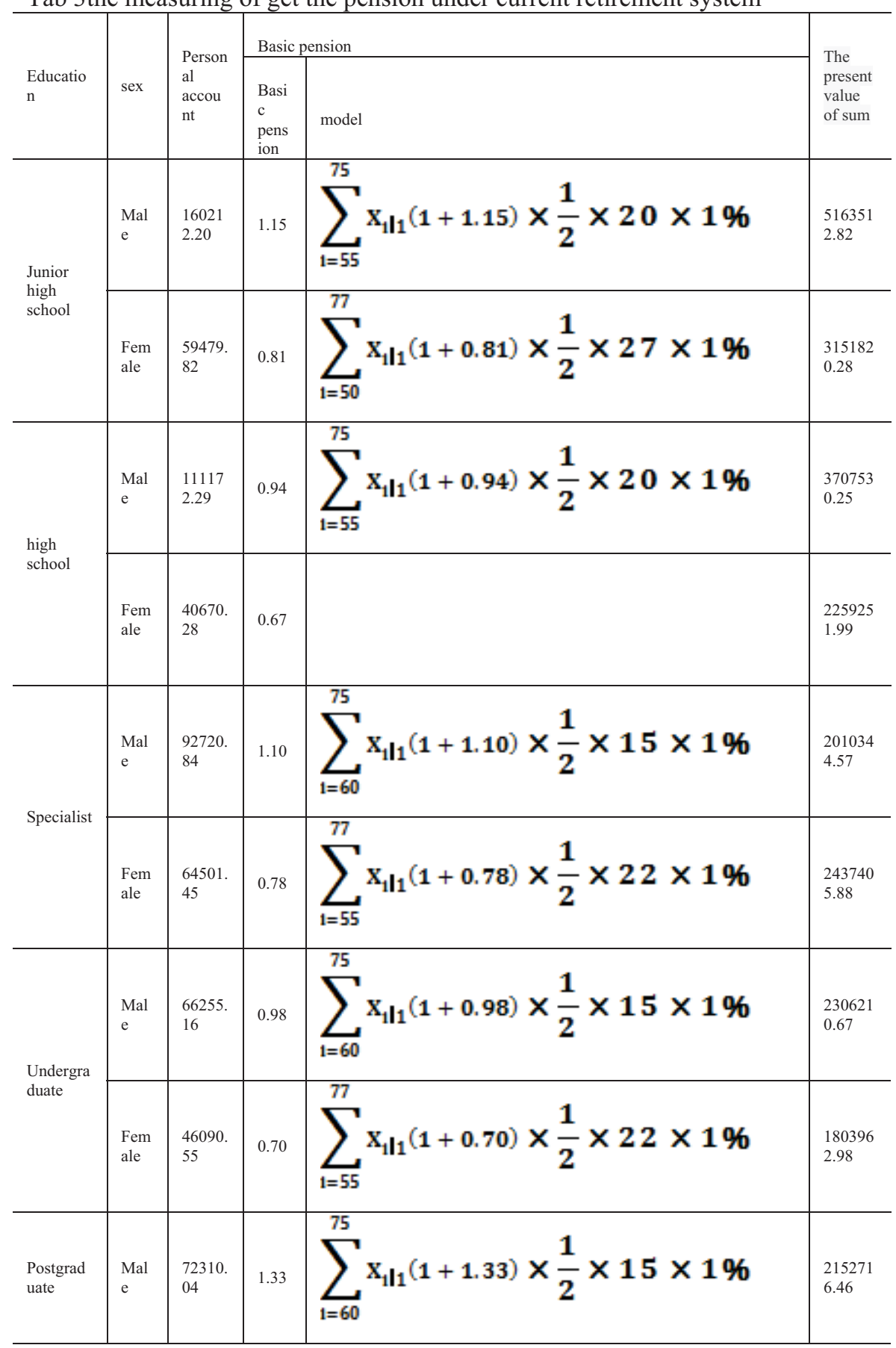




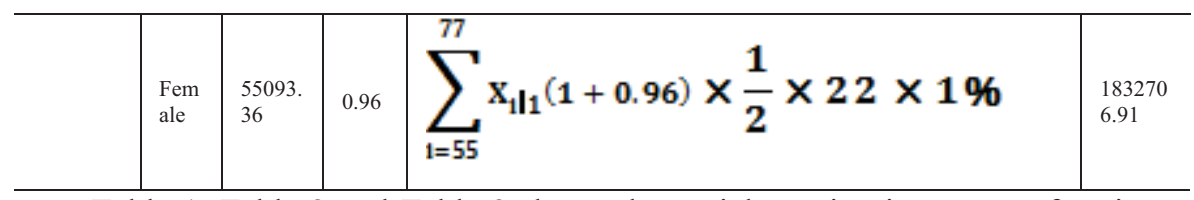

Table 1, Table 2 and Table 3 shows the social pension insurance of various types of workers in China in Table 4.It is easy to find that according to the existing retirement policy and social pension security system, most of the workers can get the social pension insurance income. However, specialist, undergraduate and graduate students of male employees of social pension insurance income is negative. This means that this part of the work of workers to pay the social pension insurance is greater than the retirement pension after retirement. From the rational "economic man" point of view, these workers tend to choose self-help savings pension, rather than participate in social endowment insurance.

Tab4income of the endowment insurance

\begin{tabular}{l|l|l|l|l}
\hline \multirow{2}{*}{ Education } & sex & $\begin{array}{l}\text { Sum } \\
\text { payment }\end{array}$ & Sum get & profits \\
\hline \multirow{2}{*}{$\begin{array}{l}\text { Junior high } \\
\text { school }\end{array}$} & Male & 3546358.57 & 5163512.82 & 1617154.25 \\
\cline { 2 - 5 } & Female & 2000186.13 & 3151820.28 & 1151634.15 \\
\hline \multirow{2}{*}{ high school } & Male & 2535271.94 & 3707530.25 & 1172258.31 \\
\cline { 2 - 5 } & Female & 1424329.50 & 2259251.99 & 834922.49 \\
\hline \multirow{2}{*}{ Specialist } & Male & 3245286.82 & 2010344.57 & -1234942.25 \\
\cline { 2 - 5 } & Female & 1828262.78 & 2437405.88 & 609143.10 \\
\hline \multirow{2}{*}{ Undergraduate } & Male & 2514538.98 & 2306210.67 & -208328.31 \\
\cline { 2 - 5 } & Female & 1410358.80 & 1803962.98 & 393604.18 \\
\hline \multirow{2}{*}{\begin{tabular}{l} 
Postgraduate \\
\cline { 2 - 5 }
\end{tabular}} & Male & 2977122.03 & 2152716.46 & -824405.57 \\
\cline { 2 - 5 } & Female & 1659329.23 & 1832706.91 & 173377.68 \\
\hline
\end{tabular}




\section{Rational analyses of the current social pension and retirement system in China}

Social pension and retirement system is an important part of the national social security system and the cornerstone of national and social stability. According to the above estimates, China's current social pension and retirement system has the following characteristics:

In Table 4 we can see that all types of workers in China only Specialist, undergraduate and graduate students of male employees of the social pension insurance income is negative, other workers can get social security benefits. In general, China's current social pension and retirement system has received support and response; it is the promotion of social endowment insurance in China has an important role in promoting.

In general, low-educated workers can get social security benefits, and highly educated workers are unable to get social security benefits, from Table 4 to see the junior high school and high school graduates of social security benefits of workers was significantly higher than the Specialist Undergraduate and Postgraduate students. The main reason is: low-qualification works of the starting working age is low, low income at work, to pay the amount of old-age insurance is small, but pay a longer time. Therefore, after retirement, the basic pension is higher. In addition, the low-qualification works are more physical nature of the earlier retirement, in the same life under the premise of pension time is also long. This policy is conducive to encourage young people to participate in social work as soon as possible, early payment of social endowment insurance.

From a gender perspective, the current social pension retirement system can protect the legitimate rights and interests of female workers. From Table 4, it can be seen that the female pensioners who graduated from junior middle schools, or those who graduated from high schools and master's degrees, have positive social security benefits, in other words, their retirement pension is greater than their Social pension insurance paid during the work. While the male employees of the social security pension benefits are different, college workers over the social pension insurance income is negative. The main reason is that there is no sex difference in the current system of employment and education and the salary system. That is to say, men and women of the same educational background have the same working time and the same wage and wage growth rate. However, China's retirement system gender differences are obvious.

General, male workers retire 5 years late than the same level of female workers. Male workers pay more than 5 years of pension insurance for female workers, but receive fewer pensions for 5 years.

Table 4 shows that the grass-roots workers graduated from junior high school and high school have higher social security benefits than the female ones, and the gap between them is lower. On the contrary, the white-collar graduates who graduated from Specialist or above are women's social security Pension income is greater than men, and the higher the difference between the two more obvious. The above analysis shows that there exist inequitable income distribution in China's current retirement system, and there is a huge difference in the social 
security benefits of all kinds of workers. And even highly educated male social pension benefits also appeared negative. This issue has a negative impact on the construction of a harmonious society, the improvement of education system and the promotion of social security. Therefore, we must carry out reform and improvement.

\section{Reform the social security system in order to design a reasonable retirement age}

China's current retirement system was formulated in 1950s. The State Council issued the "Labor Insurance Regulations" in 1951 and "Interim Measures on the retirement of state organs," in 1955, the development and implementation, there are many unreasonable. The imbalance of social security benefits hinders the smooth implementation of the social security system. Recently, the passive resistance of enterprise employees to pay the pension, delayed deferred payment of pensions, and most of the retired retirees, make up the phenomenon of such phenomena, have expressed a reality, this reality is the current statutory retirement age unreasonable. Therefore, it is necessary to re-measure the reasonable legal retirement age according to the development of society and economy.

4.1 Calculate of reasonable retirement age under current salary system and pension insurance system

Tab 5 reasonable retirement age under the current system

\begin{tabular}{|c|c|c|c|c|c|c|}
\hline \multirow{2}{*}{ Education } & \multirow{2}{*}{ sex } & \multirow{2}{*}{ Age range } & \multicolumn{2}{|c|}{ upper limit } & \multicolumn{2}{|c|}{ lower limit } \\
\hline & & & age & profit & age & profit \\
\hline \multirow{2}{*}{$\begin{array}{l}\text { Junior high } \\
\text { school }\end{array}$} & Male & $(59,60)$ & 59 & 597339.29 & 60 & -67264.01 \\
\hline & Female & $(57,58)$ & 57 & 151268.59 & 58 & $\begin{array}{l}- \\
366433.63\end{array}$ \\
\hline \multirow{2}{*}{ high school } & Male & $(58,59)$ & 58 & 364359.00 & 59 & -45089.53 \\
\hline & Female & $(58,59)$ & 58 & 201607.56 & 59 & $\begin{array}{l}- \\
194452.70\end{array}$ \\
\hline \multirow{2}{*}{ Specialist } & Male & $(58,59)$ & 58 & 190642.42 & 59 & -43300.35 \\
\hline & Female & $(59,60)$ & 59 & 181782.10 & 60 & $\begin{array}{l}- \\
130562.72\end{array}$ \\
\hline \multirow{2}{*}{ Undergraduate } & Male & $(58,59)$ & 58 & 50554.65 & 59 & $\begin{array}{l}- \\
134996.60\end{array}$ \\
\hline & Female & $(57,58)$ & 57 & 139213.84 & 58 & -27041.11 \\
\hline
\end{tabular}




\begin{tabular}{l|l|l|l|l|l|l}
\hline \multirow{2}{*}{ Postgraduate } & Male & $(56,57)$ & 56 & 28323.44 & 57 & - \\
\cline { 2 - 7 } & Female & $(55,56)$ & 55 & 170836.25 & 56 & -47405.99 \\
\hline
\end{tabular}

Table 5 gives the current education and remuneration system under the reasonable retirement age estimates. From the table available from the perspective of income distribution fairness should be the first retirement of female Postgraduate students, their reasonable retirement age should be 55 - 56 years of age, the latest retirement is the junior high school graduates and Specialist graduates of women, they Of the reasonable retirement age should be between 59--60.Therefore, other factors remain unchanged under the premise of a reasonable retirement age should be 55 - 60 between. It is basically that the current retirement age in China between 50 and 60.So it is unreasonable that blindly extend retirement age under the current compensation system.But, it is still necessary to adjust the retirement age of special uterus

Benefit theory of social pension insurance is to determine the legal basis for the retirement age is to maintain the fair distribution of social income the main expression. When the employees retire at the statutory retirement age, the retirement pension they receive is balanced with the insurance premium paid at work. This balance can not only meet the psychological needs of employees and retirees, but also to maintain the normal turnover of the social security fund and it is to maintain the balance of social security funds an important factor in the operation. When something breaks the balance, it may trigger social instability. Individual social pension security income is greater than zero (pension is greater than the pension insurance), may lead to social security fund payment difficulties, and ultimately damage the interests of retired workers; On the contrary, individual social security income is less than zero (pension is less than the pension insurance), may lead to difficulties in collecting old-age insurance, and even refused to pay the pension insurance and other events. Therefore, the social pension insurance income theory is the basic premise to determine the statutory retirement age, under the current remuneration policy to determine the male retirement age of 58 years of age, female retirement age of 57 years of age is more reasonable.

Retirement is due to old age or other incapacity to work therefore, the statutory retirement age design should take full account of labor intensity and health of workers. According to the current salary system, the legal retirement age does not fully consider the different nature of the work of the various requirements of the physical quality. Obviously, it is not reasonable.Therefore,mental and manual workers to determine the retirement age, respectively in China.The retirement age for heavy manual workers is 55 years for men and 50 years for women, and the retirement age for mental workers is 60 years for men and 55 years for men.In February, 2015, the Ministry of Human Resources and Social Security jointly issued the Notice on the Retirement Age of Women and Cadres at County Level and Female Professional and Technical Personnel with Senior Professional Titles (hereinafter referred to as the Notice) issued by the Ministry of Human Resources and Social Security. Adjust the legal 
retirement age of the woman's senior intellectuals to 60 .This "notice" is very consistent with current situation and social requirements.

From the current pay distribution system, according to the theory of social security benefits of retirement age (see Table 5), according to this calculation of the lower level of education (junior high school, high school, Specialist) in the retirement age of 57 - 60 years of age, And highly educated (Postgraduate) graduate of the mental age of $55-57$ years of age. This is contradiction with physical quality requirements. Therefore, the Task group advise that the reform of the retirement system before the salary distribution system and pension distribution system reform. The basic idea of the reform of the salary system is that it can simultaneously improve the mental workers and reduce the social pension security balance of the manual laborers (especially the heavy manual laborers).

Legal the retirement age involves the community, the need to balance the interests of all parties. With the changing times, the factors of economic development are dynamic changes. No matter what kind of theory and method cannot determine a completely reasonable unified retirement age. Therefore, the task group recommends not setting a unified retirement age, but in accordance with the theory of social pension benefits, the implementation of flexible retirement age. Then, workers can be based on their nature of work, physical condition and quality of life after retirement requirements to determine their own retirement age. Not only in line with the theory of social security benefits in retirement to meet the retirement needs of pension workers, but also fully express the work of the individual wishes and personality requirements.

At present, China's social security system is not perfect; the concept of the residents of the pension consumption is still relatively backward. In order to protect the operation and turnover of social security funds, improve the living standards of residents, The policy should be encouraged to allow workers in the physical conditions allow, As far as possible to delay retirement, increase the pensions to pay the number of years to reduce the number of pension years, to improve the amount of pension in order to improve the quality of life in old age.

\section{Acknowledgement}

Fund project: Ministry of education, Humanistic social science project of. "Study on the age decision model of the uterus in our country" (Number: 13YJA840014)

\section{Reference:}

[1]Joha Than Gruber, David Wisa. Social Security and Retirement around the World [M] The University of Chicago Press, 1998.

[2]Gasallo Vincenzo. Postponing Retirement: The Political Effect of Aging[J]. Journal of Public Economics. 2008, 92 
[3]OECD. Pensions at a Glance 2013: OECD and G20 Indicators [ M. OECD,2013 